\title{
Oxidized low-density lipoproteins induce tissue factor expression in T-lymphocytes via activation of lectin-like oxidized low-density lipoprotein
} receptor-1

\author{
Giovanni Cimmino", Plinio Cirillo², Stefano Conte', Grazia Pellegrino ${ }^{2}$, Giusi Barra $\mathbb{1}^{3}{ }^{3}$, \\ Lucio Maresca ${ }^{4}$, Andrea Morello ${ }^{2}$, Gaetano Cali ${ }^{5}$, Francesco Loffredo ${ }^{1,6}$, \\ Raffaele De Palma ${ }^{3,7}$, Giulia Arena', Tatsuya Sawamura ${ }^{8}$, Giuseppe Ambrosio', and \\ Paolo Golino (1) ${ }^{1 *}$
}

${ }^{1}$ Department of Translational Medical Sciences, Section of Cardiology, University of Campania "Luigi Vanvitelli", c/o Monaldi Hospital, Via L. Bianchi, 1, 80131 Naples, Italy; ${ }^{2}$ Department of Advanced Biomedical Sciences, Section of Cardiology, University of Naples “Federico II”, Naples, Italy; ${ }^{3}$ Department of Clinical and Experimental Medicine, Section of Clinical Immunology, University of Campania "Luigi Vanvitelli", Naples, Italy; ${ }^{4}$ Vascular Surgery Unit, Monaldi Hospital, Naples, Italy; ${ }^{5}$ Endocrinology and Experimental Oncology Institute, CNR, Naples, Italy; ${ }^{6}$ Molecular Cardiology, International Centre for Genetic Engineering and Biotechnology, Trieste, Italy; ${ }^{7}$ Institute of Protein Biochemistry, CNR, Naples, Italy; ${ }^{8}$ Department of Physiology, Shinshu University School of Medicine, Asahi, Japan; and 'Department of Cardiology, University of Perugia, Perugia, Italy

Received 25 April 2019; revised 17 July 2019; editorial decision 31 July 2019; accepted 21 August 2019

Time for primary review: 19 days

Aims

T-lymphocytes plays an important role in the pathophysiology of acute coronary syndromes. T-cell activation in vitro by pro-inflammatory cytokines may lead to functional tissue factor (TF) expression, indicating a possible contribution of immunity to thrombosis. Oxidized low-density lipoproteins (oxLDLs) are found abundantly in atherosclerotic plaques. We aimed at evaluating the effects of oxLDLs on TF expression in T cells and the role of the lectin-like oxidized low-density lipoprotein receptor-1 (LOX-1).

Methods $\mathrm{CD}^{+}$cells were isolated from healthy volunteers. Gene, protein, and surface expression of TF, as well as of and results LOX-1, were assessed at different time-points after oxLDL stimulation. To determine whether oxLDL-induced TF was LOX-1 dependent, T cells were pre-incubated with an LOX-1 inhibiting peptide (L-RBP) or with an anti-LOX1 blocking antibody. To exclude that TF expression was mediated by reactive oxygen species (ROS) generation, oxLDL-stimulated $T$ cells were pre-incubated with superoxide dismutase + catalase or with 4-Hydroxy-2,2,6,6-tetramethylpiperidine-1-oxyl (Tempol), an intracellular free radical scavenger. Finally, to determine if the observed findings in vitro may have a biological relevance, the presence of $\mathrm{CD}^{+} / \mathrm{TF}^{+} / \mathrm{LOX}-1^{+}$cells was evaluated by immunofluorescence in human carotid atherosclerotic lesions. oxLDLs induced functionally active TF expression in $T$ cells in a dose- and time-dependent manner, independently on ROS generation. No effect was observed in native LDL-treated T cells. LOX-1 expression was also induced by oxLDLs in a time- and dose-dependent manner. Pre-incubation with L-RBP or anti-LOX-1 antibody almost completely inhibited oxLDL-mediated TF expression. Interestingly, human carotid plaques showed significant infiltration of $\mathrm{CD}^{+}$cells (mainly $\mathrm{CD}^{+}$cells), some of which were positive for both TF and LOX-1.

Conclusion

oxLDLs induce functional TF expression in T-lymphocytes in vitro via interaction of oxLDLs with LOX-1. Human carotid atherosclerotic plaques contain $\mathrm{CD} 3^{+} / \mathrm{CD} 8^{+}$cells that express both TF and LOX-1, indicating that also in patients these mechanisms may play an important role.

* Corresponding author. Tel: +39081 706 4239; fax: +39 081706 4285, E-mail: paolo.golino@unicampania.it

Published on behalf of the European Society of Cardiology. All rights reserved. ( The Author(s) 2019. For permissions, please email: journals.permissions@oup.com. 


\section{Keywords Lipoproteins - Atherosclerosis • Inflammation • T-lymphocyte • Tissue factor}

\section{Graphical Abstract}

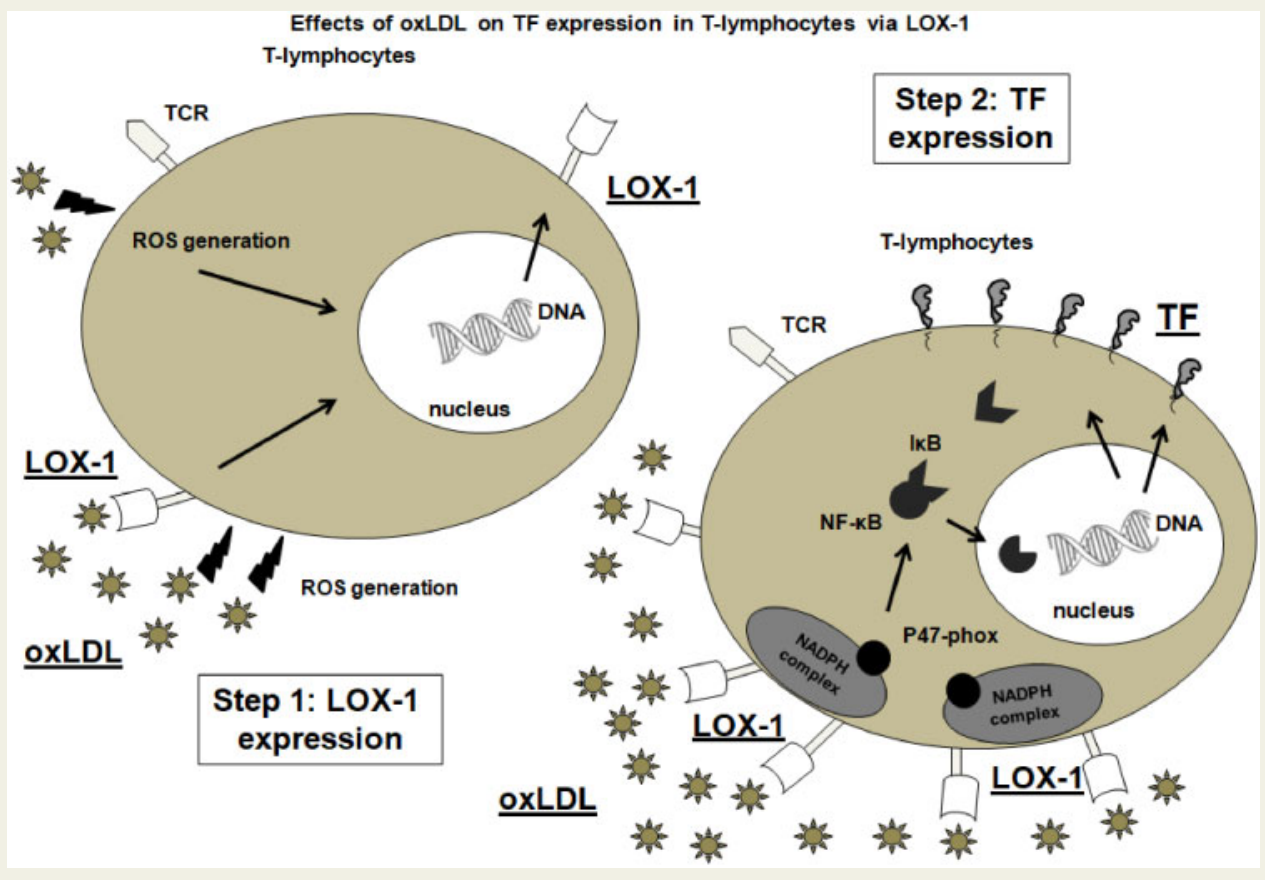

\section{Introduction}

Atherosclerosis is a lipoprotein-driven, inflammatory disease characterized by deposition of low-density lipoproteins (LDLs) and other blood-borne materials within the arterial wall of almost all vascular districts. ${ }^{1}$ Furthermore, it has been convincingly demonstrated that within coronary vessels, infiltration of immune-competent cells, such as macrophages and T-lymphocytes, plays an important role not only in the progression of atherosclerosis but also in plaque destabilization, leading to the clinical scenario of acute coronary syndromes (ACS). ${ }^{2}$

We have previously reported that coronary plaques obtained from ACS patients show a selective, oligoclonal expansion of T cells, indicating a specific, antigen-driven recruitment of T-lymphocytes within the unstable lesions. ${ }^{3}$ To date, however, the antigen(s) responsible for this recruitment still remain elusive, although it has been postulated that oxidized-LDLs (oxLDLs) might represent a good candidate. ${ }^{4-6}$ Quite recently indeed, Liu et al. ${ }^{7}$ have demonstrated that oxLDLs induce activation of T-lymphocytes in presence of dendritic cells, further supporting the notion that oxLDLs may act, under certain conditions, as a non-selfantigen. However, within the atherosclerotic plaque microenvironment, several stimuli may act simultaneously on the resident cells, including T-lymphocytes, thus contributing to their activation via mechanisms different from the 'classical' interaction of the antigen with the T-cell receptor. ${ }^{8}$ For example, as reported by our group, stimulation of T-lymphocytes with selected pro-inflammatory cytokines in vitro induce a pro-thrombotic phenotype via expression of functional tissue factor (TF), the main initiator of the coagulation cascade. ${ }^{9}$ Interestingly, this phenomenon seems to occur also in vivo in ACS patients. ${ }^{8}$
Internalization and degradation of oxLDLs is mediated by a lectin-like $52-k D$ receptor, namely lectin-like oxidized low-density lipoprotein receptor-1 (LOX-1). ${ }^{10}$ Since its discovery, several studies have described the role of LOX-1 in atherosclerosis and cardiovascular disease. ${ }^{11}$

According to the available data, we hypothesized that oxLDLs might induce TF expression in T-lymphocytes via a mechanism different from the immunological activation of $T$ cells, i.e. antigen/T-cell receptor interaction. In particular, the role of LOX-1, also expressed in T-lymphocytes, ${ }^{12}$ was investigated. We report here that oxLDLs, but not native LDLs, induce functionally active TF expression in T cells via interaction with LOX-1 and that human carotid plaques contain $\mathrm{CD}^{+} /$ $\mathrm{TF}^{+} / \mathrm{LOX}-1^{+}$cells, providing evidence for a novel mechanism of T-cell activation within atherosclerotic plaques. The potential implications of these findings in human disease are also discussed.

\section{Methods}

Expanded methods are provided in Supplementary material online.

\subsection{Experimental protocol}

LDLs (density 1.019-1.063 g/mL) and oxLDLs were prepared as previously described. ${ }^{13}$ T-lymphocytes were isolated from daily fresh human buffy coats of 15 healthy volunteers as previously described. ${ }^{9}$ A written informed consent was obtained from each subject. The protocol was approved by the local ethical committee and conform the principles outlined in the declaration of Helsinki. 
In preliminary experiments, a dose-response curve to oxLDLs was performed $(25,50$, and $100 \mu \mathrm{g} / \mathrm{mL})$. oxLDLs at $25 \mu \mathrm{g} / \mathrm{mL}$ induced a slight but non-significant increase in TF expression, while a significant increase in TF expression was observed at 50 and $100 \mu \mathrm{g} / \mathrm{mL}$, although the latter was associated with some cytotoxicity. Based on these preliminary experiments, T cells $\left(1 \times 10^{6} / \mathrm{mL}\right)$ were incubated with either oxLDLs (50 and $100 \mu \mathrm{g} / \mathrm{mL}$ ) or native, non-oxidized LDLs as internal control. To determine whether oxLDLs induce expression of TF in T cells, TF mRNA analysis was performed at different time-points $(4,8,12,18,24$, 48 , and $72 \mathrm{~h}$ ) following stimulation. TF protein levels by western blot, as well as flow cytometry analysis and TF functional assay in intact cells were performed at $72 \mathrm{~h}$. To determine whether oxLDL-induced TF expression in T-lymphocytes was mediated by expression and activation of LOX-1, further experiments were performed. First, LOX-1 expression was evaluated following stimulation with oxLDLs, as above described, both at gene and protein level. In a second set of experiments, T cells were pre-incubated for $30 \mathrm{~min}$ with an LDL receptor blocking peptide (L-RBP, Cayman Chemical, Ann Arbor, MI) $(5$ and $10 \mu \mathrm{g} / \mathrm{mL}$ final concentration) or a neutralizing monoclonal antibody against human LOX-1 (TS92, $10 \mu \mathrm{g} / \mathrm{mL}$; characteristics of the antibody were described in previous reports). ${ }^{14,15}$ Then, T-lymphocytes were incubated with oxLDLs $(50 \mu \mathrm{g} / \mathrm{mL})$. TF gene, protein, and activity levels were evaluated as above described.

To determine which intracellular signalling pathways are activated by LOX-1/oxLDL interaction, the contributions of p47 (one of the major constituent of NADPH oxidase [NOX]), as well as of NF- $\kappa B$ (by western blot and translocation assay as previously described ${ }^{16}$ ), were investigated. The effects of NOX inhibition by diphenyleneiodonium (DPI, obtained from Sigma-Aldrich, St. Louis, MO, D2926) were also evaluated. T cells were pre-treated with DPI at final concentration of $500 \mu \mathrm{M}$ as already described ${ }^{17}$ for $1 \mathrm{~h}$ and subsequently stimulated with oxLDL $(50 \mu \mathrm{g} / \mathrm{mL})$ for 24 and $48 \mathrm{~h}$ for mRNA analysis.

Furthermore, to determine whether the observed effects on TF expression in oxLDLs stimulated T cells were specific of LOX-1/oxLDL interaction or caused by a generic lipid peroxidation/reactive oxygen species (ROS) generation phenomenon, additional experiments were performed: (i) T cells were stimulated with $\mathrm{H}_{2} \mathrm{O}_{2}(50 \text { and } 100 \mu \mathrm{M})^{18}$ and TF expression was evaluated at gene and protein levels. LOX-1 gene expression was also investigated; (ii) $\mathrm{T}$ cells were pre-incubated with superoxide dismutase $(\mathrm{SOD}, 500 \mathrm{U} / \mathrm{mL})^{16,19}$ and catalase $(300 \mathrm{U} / \mathrm{mL})^{20,21}$ for $30 \mathrm{~min}$ and then stimulated with oxLDLs $50 \mu \mathrm{g} / \mathrm{mL}$; (iii) $\mathrm{T}$ cells were pre-incubated for $1 \mathrm{~h}$ with 4-Hydroxy-2,2,6,6-tetramethylpiperidine-1-oxyl (Tempol, $10 \mu \mathrm{M}$ ), a membrane-permeable aminoxyl-type free radical scavenger, with unique antioxidant properties. ${ }^{22,23}$ Cells were then stimulated with oxLDLs and expression of TF was evaluated as above described. The amount of lipid peroxidation was determined by measuring lipid peroxidation products both after oxLDLs and $\mathrm{H}_{2} \mathrm{O}_{2}$ stimulation.

For each peripheral blood mononuclear cell (PBMC) preparation, three independent experiments for all of the conditions above described were performed.

\subsection{Real-time PCR}

Total RNA was isolated using Trizol Reagent, according to the manufacturer's protocol. Amplification of LOX-1 from cDNA was performed using the following primers (Sigma-Aldrich): fw: 5'-TGGGAAAAG AGCCAAGAGAA-3', rev: 5'-TAAGTGGGGCATCAAAGGA-3'. TF and housekeeping gene TBP (TATA Box protein) primers were previously described. ${ }^{9}$

\subsection{Collection of cell lysates and protein expression}

Protein analysis was performed on T-cell lysates at $72 \mathrm{~h}$ following stimulation with oxLDLs and at 4, 8, 12, 18, and $24 \mathrm{~h}$ after stimulation with $\mathrm{H}_{2} \mathrm{O}_{2}$. For molecular pathways analysis, cell lysates were collected 8, 16, and $24 \mathrm{~h}$ following stimulation with oxLDLs $(50 \mu \mathrm{g} / \mathrm{mL})$ with or without L-RBP $(10 \mu \mathrm{g} / \mathrm{mL})$ or a blocking monoclonal antibody against human LOX-1 (TS92, $10 \mu \mathrm{g} / \mathrm{mL}$ ). Blots were incubated overnight at $4^{\circ} \mathrm{C}$ with anti-TF antibody (Affinity Biologicals) diluted 1:1000 in TBS with 0.1\% Tween-20 and 2.5\% non-fat dry milk. For molecular pathways analysis,

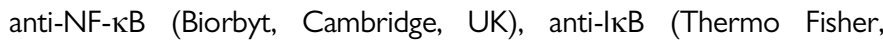
Waltham, MA), and anti-p47 phosphorylated antibody (Thermo Fisher) were used.

\subsection{Flow cytometry analysis}

Ten million $\mathrm{T}$ cells, isolated as above described, were plated in X-Vivo medium and treated with oxLDL $(50 \mu \mathrm{g} / \mathrm{mL})$ for $72 \mathrm{~h}$. Surface TF expression as well as CD8/CD4 subpopulations characterization was performed.

\subsection{TF activity in intact $T$ cells}

TF procoagulant activity was measured as previously described. ${ }^{9}$

\subsection{Quantification of lipid peroxidation products}

The extent of lipid peroxidation in cell lysates was determined by measuring malonyldialdehyde (MDA) levels, a secondary lipid peroxidation product. The thiobarbituric acid method (TBARS assay kit, Cayman Chemical) was used and results were expressed as micromolar of MDA generated. $^{13}$

\subsection{Confocal microscopy of $T$ cells}

To evaluate surface expression and distribution of LOX-1 on T-cell membrane, we performed confocal microscopy experiments. Briefly, T-lymphocytes $\left(3 \times 10^{6}\right)$ were incubated with oxLDLs $(50 \mu \mathrm{g} / \mathrm{mL})$ for $72 \mathrm{~h}$. Cells were then incubated with primary antibody (Anti-LOX 1, purchased from Abcam, Cambridge, UK) for $1 \mathrm{~h}$ at RT, extensively washed in phosphate buffer saline (PBS) and incubated with secondary antibody (Alexafluor 546 goat anti mouse) for $1 \mathrm{~h}$ at RT. Cells were extensively washed in PBS, spotted on microscope slides, and analysed.

\subsection{Immunohistochemistry of human carotid atherosclerotic lesions}

To determine whether T-lymphocytes co-localize with TF in vivo, immunohistochemistry staining was performed using $4 \mu \mathrm{m}$ thick formalinfixed, paraffin-embedded (FFPE) tissue sections of atherosclerotic plaques. Serial adjacent sections were treated as previously described. ${ }^{9,24}$

\subsection{Immunofluorescence of human carotid atherosclerotic lesions}

Immunofluorescence was performed using $4 \mu \mathrm{m}$ thick FFPE tissue sections of carotid plaques. Slides were treated as previously described. ${ }^{25}$ To evaluate the CD3 subset population co-expressing TF/LOX-1, immunofluorescence (IF) was carried out by mean of Opal Multiplex IF Assay $^{26}$ (Perkin Elmer, Waltham, MA, USA) (gift of Prof. G. Matarese, University 'Federico Il', Naples, Italy) as suggested by the manufacturer using $4 \mu \mathrm{m}$ thick FFPE tissue sections from atheroma. 


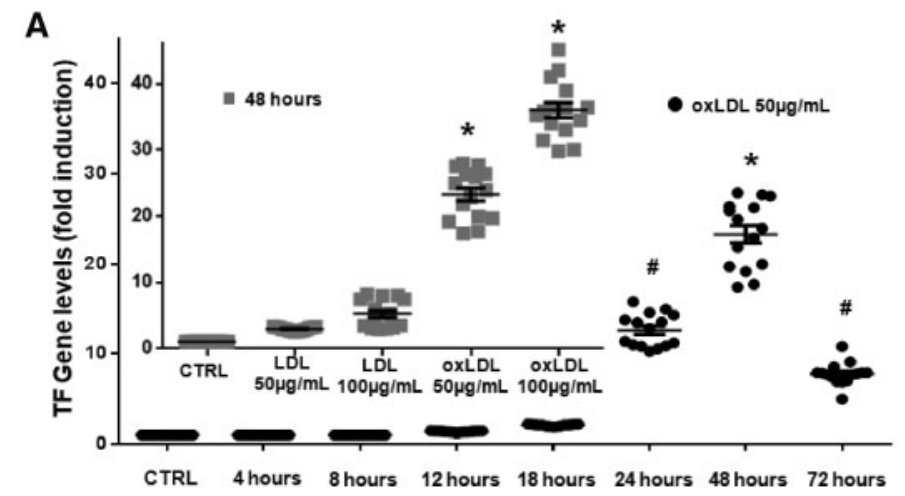

B
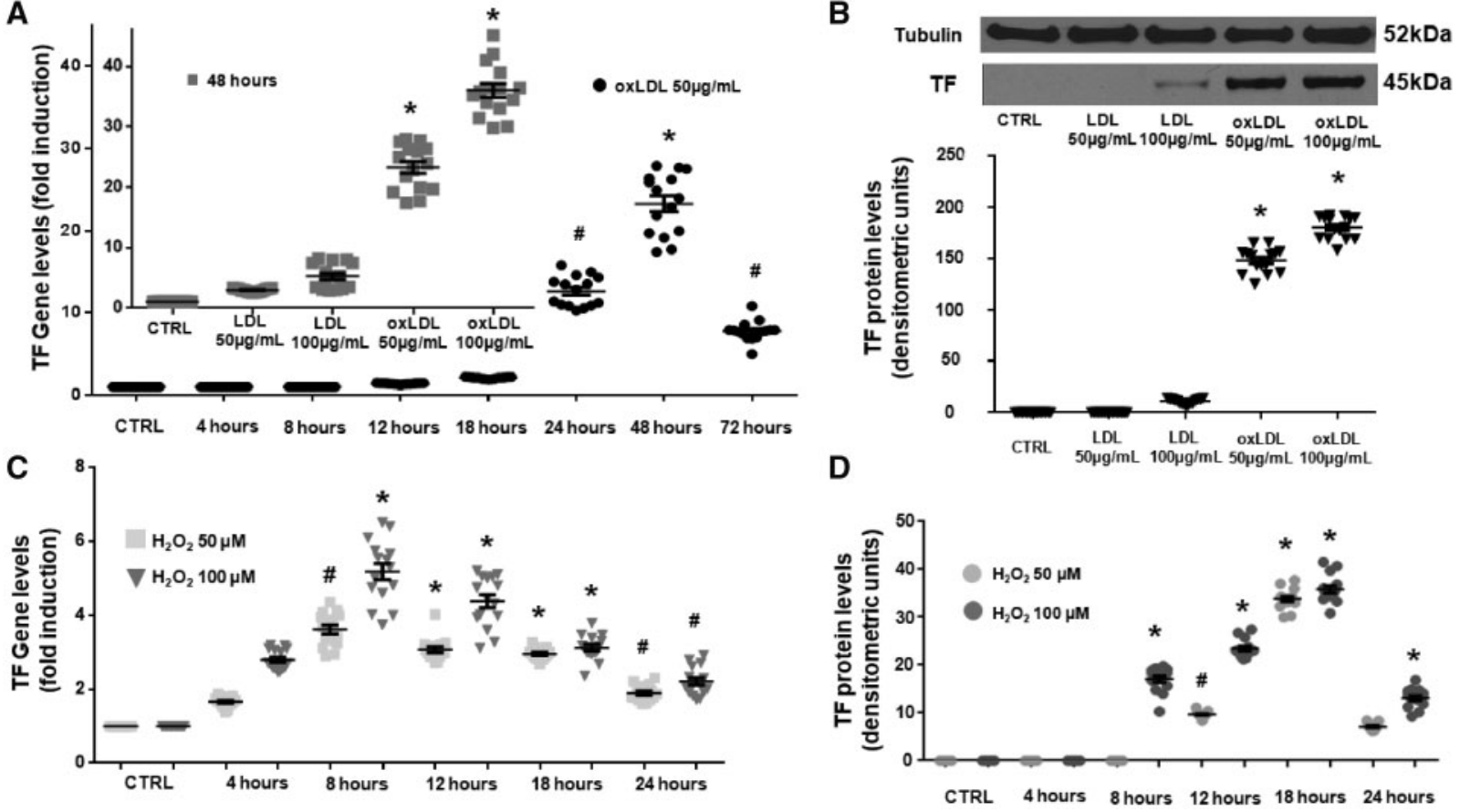

Figure I Effects of oxLDLs and $\mathrm{H}_{2} \mathrm{O}_{2}$ on TF expression by T-lymphocytes in vitro. CD3 ${ }^{+}$lymphocytes were isolated from freshly prepared buffy coats and stimulated with either native LDLs, oxLDLs, or $\mathrm{H}_{2} \mathrm{O}_{2}$. (A) oxLDLs induced a time- and dose-dependent increase in TF gene levels, as TF gene expression increased significantly at $24 \mathrm{~h}$, peaked at $48 \mathrm{~h}$, and decreased significantly at $72 \mathrm{~h}$ following incubation with oxLDLs. Each column represents the mean $\pm \mathrm{SE}$ of 15 experiments in triplicate ( ${ }^{\#} P<0.01, * P<0.001$ vs. Control; one-way ANOVA with Tukey's post hoc test). Graph in the inset shows the dose-dependent effects of oxLDLs $(50$ and $100 \mu \mathrm{g} / \mathrm{mL}$ ) at $48 \mathrm{~h}$. (B) Changes in TF protein levels (measured by western blot analysis on cell lysates) paralleled those observed for TF gene. TF protein significantly increased at $72 \mathrm{~h}$ in oxLDL-treated cells in a dose-dependent manner, while only a slight effect was observed in LDLstimulated cells. Each column represents the mean \pm SE of 15 experiments in triplicate ( $* P<0.001$ vs. Control; one-way ANOVA with Tukey's post hoc test). (C) Incubation of T-lymphocytes with $\mathrm{H}_{2} \mathrm{O}_{2}$ induced a slight expression of TF gene in a dose- and time-dependent manner. However, the time-course of TF expression was much earlier as compared to oxLDL-treated cells: TF gene levels reached the highest value at $8 \mathrm{~h}$ with a five-fold increase as compared to unstimulated cells. Each column represents the mean $\pm S E$ of 15 experiments in triplicate $\left({ }^{\#} P<0.01, * P<0.001\right.$ vs. Control; one-way ANOVA with Tukey's post hoc test). (D) Changes in TF protein levels (measured by western blot analysis on cell lysates) paralleled those observed for TF gene. TF protein significantly increased at $8 \mathrm{~h}$ in $\mathrm{H}_{2} \mathrm{O}_{2}$-treated cells in a dose-dependent manner. Each column represents the mean $\pm \mathrm{SE}$ of 15 experiments in triplicate $\left({ }^{\#} P<0.01\right.$, $* P<0.001$ vs. Control; one-way ANOVA with Tukey's post hoc test).

\subsection{Statistical analysis}

Results are expressed as mean \pm SE. All data from in vitro experiments were evaluated by D'Agostino-Pearson test for normal distribution. One-way ANOVA followed by the Tukey test was used for multiple comparisons. All analyses were performed using the GraphPad Prism 6.00 for Windows software (GraphPad Software, San Diego California, USA).

\section{Results}

\section{1 oxLDLs induce TF gene and protein expression in T-lymphocytes}

Incubation of T-lymphocytes with oxLDLs, but not with native LDLs, induced TF gene expression in a dose- and time-dependent manner (Figure $1 \mathrm{~A}$ and inset), without affecting cell viability up to $50 \mu \mathrm{g} / \mathrm{mL}$ (data not shown). TF mRNA levels remained stable at baseline values up to $18 \mathrm{~h}$, increased up to about 25 -fold the control values at $48 \mathrm{~h}$ of incubation with oxLDLs $50 \mu \mathrm{g} / \mathrm{mL}$, and significantly decreased at $72 \mathrm{~h}$
(Figure 1A). Taking into account the time-course of TF mRNA, protein levels were investigated by western blot up to $72 \mathrm{~h}$ following oxLDL stimulation. No detectable bands were observed at earlier time point (18 and $24 \mathrm{~h}$, while a faint band was present at $48 \mathrm{~h}$, data not shown). TF protein levels significantly increased at $72 \mathrm{~h}$ following exposure to oxLDLs (Figure 1B). No significant effect was observed in $T$ cells exposed to native LDLs.

It has been previously demonstrated that oxLDLs result in a significant peroxidation of cellular lipid membranes. ${ }^{27,28}$ Thus, to determine if the observed effects of oxLDLs on TF expression in T cells were nonspecifically related to an increase in lipid peroxidation and/or ROS generation, T-lymphocytes were stimulated with $\mathrm{H}_{2} \mathrm{O}_{2}(50$ and $100 \mu \mathrm{M})$. $\mathrm{H}_{2} \mathrm{O}_{2}$ at both concentrations determined an increase in TF expression both at gene and protein levels (Figure $1 C$ and D). LOX-1 was also induced in a dose- and time-dependent manner (Supplementary material online, Figure S1). However, $\mathrm{H}_{2} \mathrm{O}_{2}$ stimulation of $\mathrm{T}$ cells resulted in a much lower TF expression, as compared to oxLDLs. Most importantly, induction of TF by $\mathrm{H}_{2} \mathrm{O}_{2}$ was much earlier with respect to oxLDLs, as TF gene was already significantly induced at $4 \mathrm{~h}$ of stimulation. This timelag in TF expression between oxLDLs and $\mathrm{H}_{2} \mathrm{O}_{2}$ suggests that the effects 
A

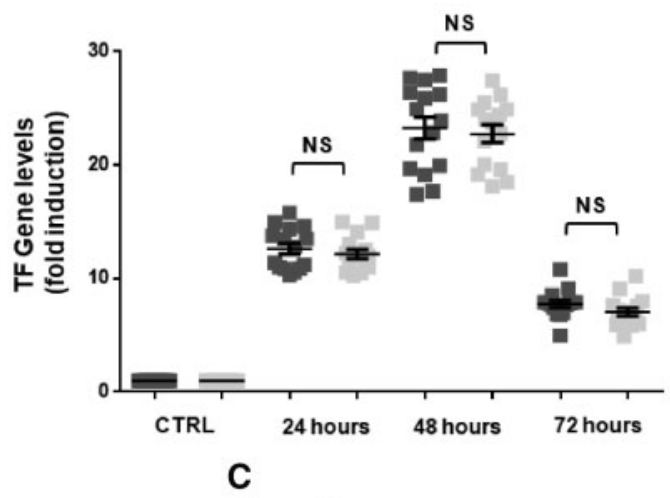

B

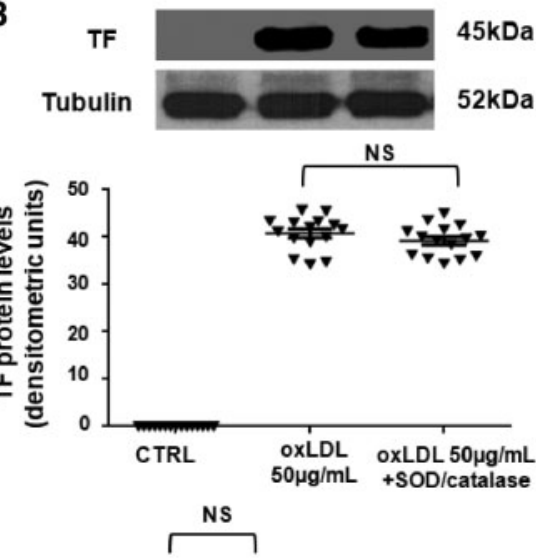

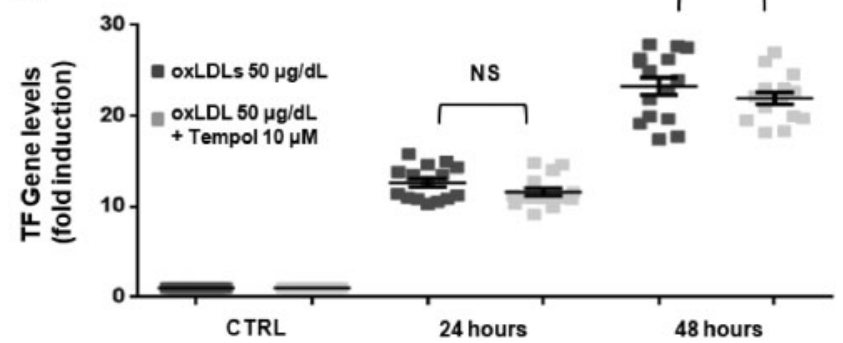

Figure 2 Effects of antioxidants (superoxide dismutase, catalase, and Tempol) on TF expression induced by oxLDLs. T-lymphocytes were pre-incubated with superoxide dismutase $(\mathrm{SOD}, 500 \mathrm{U} / \mathrm{mL})$ and catalase $(300 \mathrm{U} / \mathrm{mL})$ or Tempol $(10 \mu \mathrm{M})$ before stimulation with oxLDLs. SOD and catalase or Tempol did not significantly affect TF expression at gene $(A$ and $C$ ) and protein levels $(B)$. Each column represents the mean $\pm S E$ of 15 experiments in triplicate. Statistical analysis made by one-way ANOVA with Tukey's post hoc test. NS, not significant.

of oxLDLs were not related to an increase in lipid peroxidation but rather mediated via activation of some other intracellular pathways. Furthermore, pre-incubation with SOD and catalase did not significantly affect oxLDL-induced TF expression, both at gene and protein levels (Figure $2 A$ and $B$ ), indicating that ROS generation does not significantly contribute to TF induction by oxLDLs. To strengthen these findings, we have also evaluated the effect of Tempol, an antioxidant that permeates biological membranes, on oxLDL-treated $T$ cells. Pre-incubation with Tempol, similarly to SOD and Catalase, did not significantly affect oxLDL-induced TF expression (Figure 2C).

\subsection{TF induced in T-lymphocytes by oxLDLs is translocated to the plasma membrane and is functionally active}

Fluorescence-activated cell sorting (FACS) analysis showed that oxLDLinduced TF was translocated to the cell membrane of $T$ cells as compared to LDL-stimulated or control cells (Supplementary material online, Figure S2). Of the overall $\mathrm{CD}^{+}$T-lymphocyte population, $61.1 \pm 2.9 \%$ were $\mathrm{CD}^{+}$cells, while $33.6 \pm 2.4 \%$ were $\mathrm{CD}^{+}$cells. Both unstimulated subtypes did not significantly express TF on their membrane, while following stimulation with oxLDLs, $7.3 \pm 2.1 \%$ of $\mathrm{CD}^{+}$and $4.9 \pm 1.5 \%$ of $\mathrm{CD}^{+}$were also $\mathrm{TF}^{+}$(Figure $3 \mathrm{~A}$ ). Most importantly, surface-expressed TF was also functional as shown in the activity assay experiments reporting a significant increase in FXa generation from intact T-lymphocytes (Figure 3B).

\section{3 oxLDLs induce TF in T-lymphocytes via expression of LOX-1 and activation of NF- $\kappa B$ pathway: role of NADPH oxidase}

The time-lag of TF expression in oxLDL-stimulated $\mathrm{T}$ cells as compared to $\mathrm{H}_{2} \mathrm{O}_{2}$-stimulated cells suggested that the effects of oxLDLs were mediated by activation of a different intracellular pathway. Thus, we investigated whether oxLDL-induced TF expression was mediated by expression of LOX-1, the scavenger receptor of oxLDLs. Incubation of T cells with oxLDLs, but not with LDLs, induced expression of LOX-1 in a dose- and time-dependent manner (Figure $4 A$ and inset). Gene levels remained stable at baseline values up to $12 \mathrm{~h}$. At $18 \mathrm{~h}$, a two-fold increase in LOX-1 gene levels was observed when $T$ cells were incubated with oxLDLs $(50 \mu \mathrm{g} / \mathrm{mL})$, peaking up to six-fold the control values at $48 \mathrm{~h}$ (Figure 4A). Interestingly, confocal microscopy analysis revealed that unstimulated $T$ cells express almost undetectable levels of LOX-1 on their surface (Figure $4 B$ ); in contrast, exposure to oxLDLs $(50 \mu \mathrm{g} / \mathrm{mL})$ for $72 \mathrm{~h}$ highly increased LOX-1 expression on T-cell surface (Figure 4B).

To verify whether TF expression in oxLDL-treated T-lymphocytes was related to LOX-1 activation, we pre-treated $T$ cells with a lowdensity lipoprotein receptor blocking peptide (L-RBP) and anti-LOX-1 blocking antibody. Pre-incubation with L-RBP, as well as with the antiLOX-1 antibody resulted in a significant suppression of oxLDL-induced TF expression both at gene and protein levels (Figure 5A, B, D, and E). TF procoagulant activity was also significantly reduced by both, L-RBP and TS92 (Figure 5C). Of note is the finding that L-RBP did not affect LOX-1 gene expression, as shown in Figure 5D. 
A

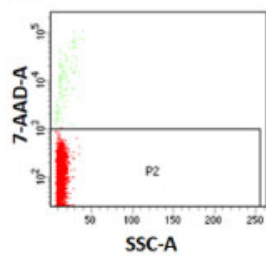

SSC-A

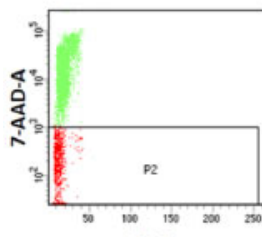

SSC-A

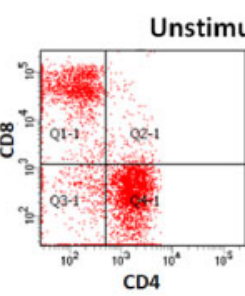

Unstimulated T-cells

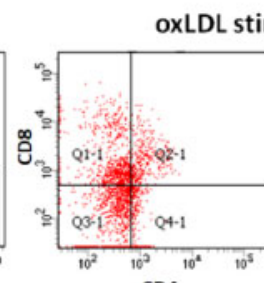

CD4

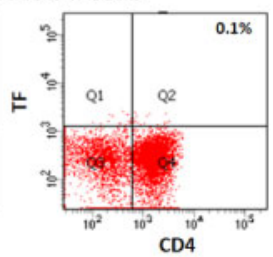

CD4

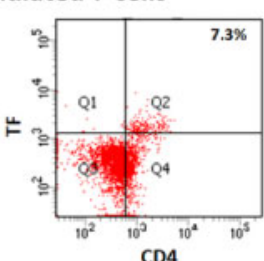

B
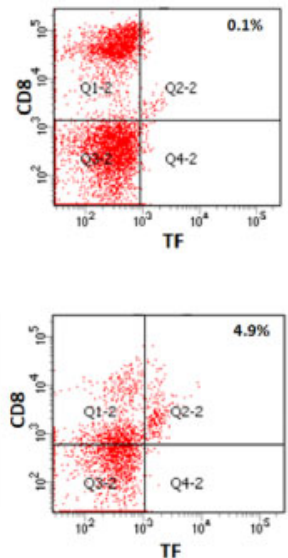

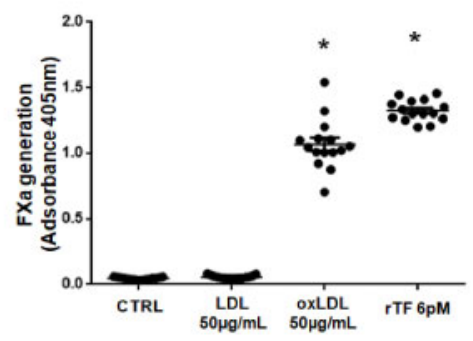

Figure 3 TF surface expression in oxLDL-treated T-lymphocytes. (A) FACS analysis was performed on live cells (red colour in 7-AAD-A box) and showed that oxLDL-induced TF was translocated to the cell membrane of T cells. Because of oxLDL toxicity some cells died (green colour), thus reducing the total cell population. Of the overall $\mathrm{CD}^{+}$T-lymphocyte population, $61.1 \pm 2.9 \%$ were $\mathrm{CD} 4^{+}$cells, while $33.6 \pm 2.4 \%$ were $\mathrm{CD} 8^{+}$cells. Both unstimulated subtypes did not significantly express TF on their membrane, while following stimulation with oxLDLs, $7.3 \pm 2.1 \%$ of $C D 4^{+}$and $4.9 \pm 1.5 \%$ of $C D 8^{+}$ were also $\mathrm{TF}^{+}$(Figure $3 A$ ). (B) TF procoagulant activity in intact T cells was measured by a modified chromogenic TF assay (see text for details). oxLDL stimulation resulted in a significant increase in FXa generation, as compared to unstimulated cells or cells treated with native LDLs, indicating that TF was translocated to the cell membrane in an active form. Activity of 6 pM recombinant re-lipidated TF ( $\mathrm{rTF}$ ) is reported as an internal control. Each column represents the mean \pm SE of 15 experiments in triplicate ( $* P<0.001$ vs. Control; one-way ANOVA with Tukey's post hoc test).

Binding of oxLDLs to LOX-1 resulted in activation of NADPH oxidase (NOX) on the cell surface, as suggested by the increase in intracellular $\mathrm{p} 47$ levels, which in turn resulted in increased cytosolic levels of $\mathrm{NF}-\kappa \mathrm{B}$ and reduced levels of $\mathrm{I} \mathrm{KB}$ (Figure $6 \mathrm{~A})$. The NOX is a multicomponent enzyme with up to six subunits, including $\mathrm{p} 47-$ phox $^{29}$; NOX activation on the cell surface usually results in intracellular ROS formation, ultimately leading to the redox-sensitive NF- $\mathrm{KB}$ signalling pathway. ${ }^{30,31}$ Interestingly, pre-incubation with the L-RBP significantly reduced $\mathrm{p} 47$ phosphorylation and NF- $\kappa B$ activation, while it increased $I \kappa B$ levels (Figure $6 \mathrm{~A}$ ). NF-KB translocation is also reduced by anti-LOX-1 antibody (Figure 6B). Furthermore, DPI, a potent inhibitor of NADH/NADPH oxidase, ${ }^{17}$ resulted in a significant inhibition of TF gene expression (Figure 6C).

To evaluate if the observed effects oxLDLs on TF expression were related at least in part to the lipid peroxidation induced by oxLDLs, we have measured lipid peroxidation products, expressed as concentration of MDA levels following stimulation with oxLDLs or $\mathrm{H}_{2} \mathrm{O}_{2}$. MDA levels were significantly higher in $\mathrm{H}_{2} \mathrm{O}_{2}$-treated cells at both concentrations, as compared to oxLDL-treated cells (Supplementary material online, Figure S3A). However, while incubation of $\mathrm{T}$ cells with $\mathrm{H}_{2} \mathrm{O}_{2}$ induced expression of LOX-1 mRNA in a dose- and time-dependent manner to a higher extent as compared to oxLDLs (Supplementary material online, Figure $\mathrm{S} 3 \mathrm{~B}$ ), $\mathrm{H}_{2} \mathrm{O}_{2}$ induced only a slight increase in TF expression, again as compared to oxLDL-stimulated cells (Supplementary material online, Figure S3C).

\subsection{T-lymphocytes in human carotid atherosclerotic plaques express both LOX-1 and TF on their surface}

Immunohistochemistry staining of atherosclerotic lesions collected from patients undergoing thromboendarterectomy (TEA) resulted cell enriched, as evidenced by haematoxylin and eosin staining (Figure 7 , Panel 1A). Some of these cells were T-lymphocytes, as they were positive for CD3 antigen (Figure 7, Panel 1B), some of which were also positive for TF antigen (Figure 7, Panel 1C).

\subsection{Immunofluorescence on human carotid atherosclerotic lesion}

We asked if T-lymphocytes present in atherosclerotic lesions expressing TF were also able to express LOX-1 protein. We performed immunofluorescent staining of human carotid atherosclerotic lesions with rabbit monoclonal anti-CD3 and mouse monoclonal anti-LOX-1 antibodies, or on consecutive serial section, rabbit polyclonal anti-TF. Results are shown in Supplementary material online, Figure S4. T-lymphocytes $\mathrm{CD}^{+}$expressed LOX-1 and TF. Successively we asked which class of T-lymphocytes was represented in human carotid atherosclerotic lesions. We performed immunofluorescence and confocal microscopy on FFPE $4 \mu \mathrm{m}$ thick sections from human carotid atherosclerotic lesions using the Opal kit (see Section 2) with antibodies anti CD4, TF, LOX-1, and on a consecutive serial section with antibodies anti CD8, TF, and LOX-1. As shown in Figure 7, Panel 2, in carotid atherosclerotic lesions, lymphocytes $\mathrm{CD}^{+}$that were also $\mathrm{TF}+$ and LOX-1+ were present. Antibody anti CD4 gave no staining.

\section{Discussion}

In the present study, we report for the first time that oxLDLs but not native LDLs induce a pro-thrombotic phenotype in T-lymphocytes by inducing TF expression via activation of LOX-1 receptor. Of note is the observation that TF was translocated to the cell membrane and was functionally active. This observation is in line with and extends our 


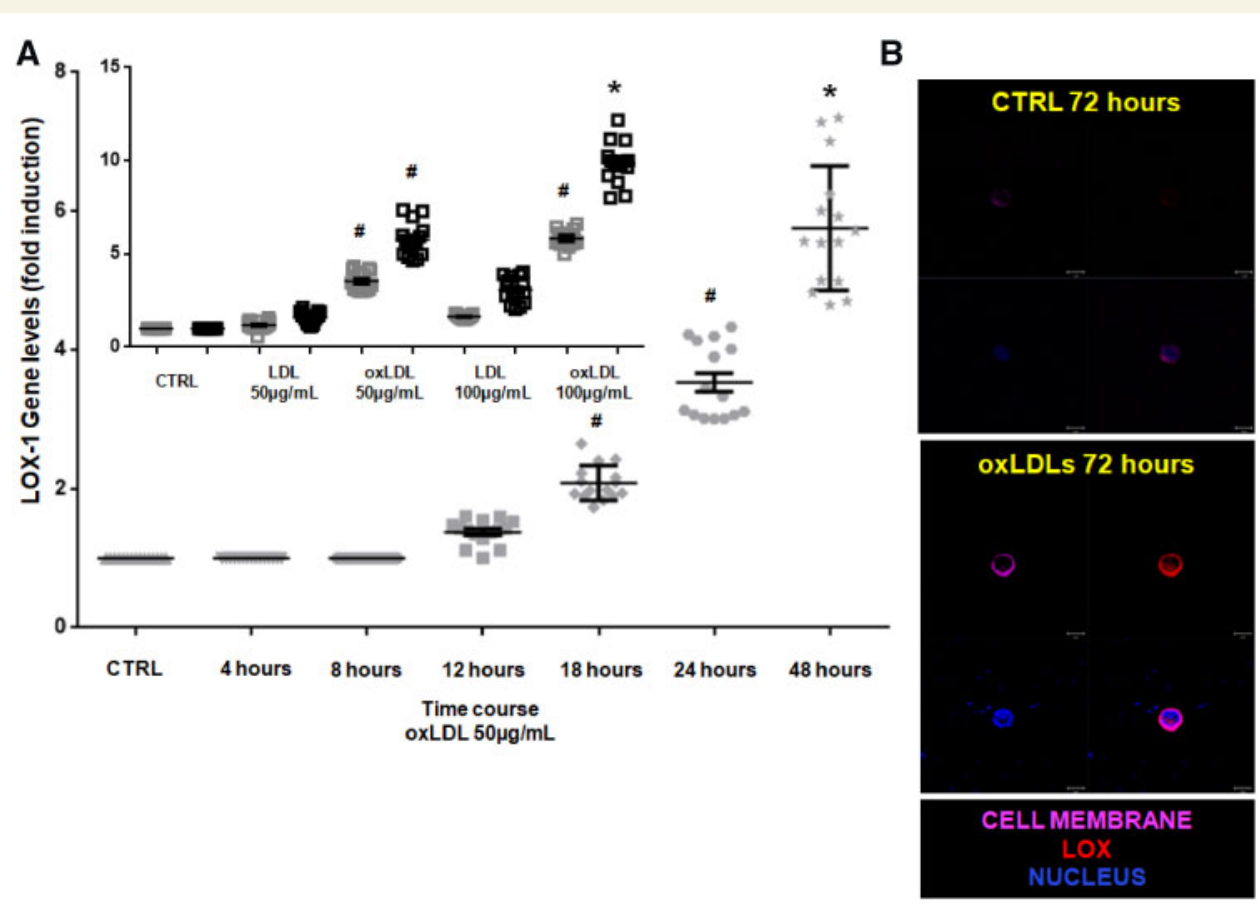

Figure 4 Effects of oxLDLs on LOX-1 expression by T-lymphocytes in vitro. CD3 ${ }^{+}$lymphocytes were isolated from freshly prepared buffy coats and stimulated with either native LDLs or oxLDLs. $(A)$ oxLDLs induced a time- and dose-dependent increase in LOX-1 gene levels, as its expression increased significantly at 18,24 , and $48 \mathrm{~h}$ following incubation with oxLDLs. Each column represents the mean \pm SE of 15 experiments in triplicate $\left({ }^{\#} P<0.01,{ }^{*} P<0.001\right.$ vs. Control; one-way ANOVA with Tukey's post hoc test). Graph in the inset shows the dose-dependent effects of oxLDLs (50 and $100 \mu \mathrm{g} / \mathrm{mL})$ at 24 and $48 \mathrm{~h}$. (B) For confocal microscopy experiments, T-lymphocytes $\left(3 \times 10^{6}\right)$ were incubated with oxLDLs $(50 \mu \mathrm{g} / \mathrm{mL})$ for $72 \mathrm{~h}$. Cells were then incubated with $0.5 \%$ Cell Marker Deep Red, fixed in 4\% para-formaldehyde and stained with a primary antibody anti-human LOX-1 and incubated with a secondary antibody. Experiments were carried out on an inverted and motorized microscope. Fluorescence emission was revealed by main dichroic beam splitter and variable secondary dichroic beam splitter. Triple staining fluorescence images were acquired separately in the blue, red, and infra-red channel. Unstimulated cells expressed very low (almost undetectable) levels of LOX-1 on cell surface (red colour). Exposure to oxLDLs ( $50 \mu \mathrm{g} / \mathrm{mL}$ ) for $72 \mathrm{~h}$ highly increases LOX-1 expression on T-cell surface.

previous findings that selected pro-inflammatory cytokines may induce active TF expression in isolated T cells (cells membrane and bearing microparticles ${ }^{9}$ ) in vitro and in patients with $\mathrm{ACS}^{8}$

Another interesting finding of the present study is that the effects on $T$ cells were not related to an increase in oxidative stress via lipid peroxidation/ROS generation but instead were mediated by the induction/ activation of LOX-1. Indeed, experiments conducted in presence of L-RBP, an inhibitor of LDL binding to its receptor, or a blocking monoclonal antibody against human LOX-1, almost completely suppressed oxLDL-induced TF expression.

We have also analysed the expression of TF in T-cell resident within human atherosclerotic lesions obtained from patients undergoing TEA. Immunohistochemistry analysis showed that these lesions were enriched in $\mathrm{CD}^{+} / \mathrm{CD}^{+}$cells, most of which were also $\mathrm{TF}^{+}$and $\mathrm{LOX}-1^{+}$. In addition, immunofluorescence analysis of the same plaques revealed the presence of T cells expressing both TF and LOX-1, indicating the potential clinical relevance of the findings observed in vitro.

Taken together, the data of the present study demonstrate, for the first time, that T-lymphocytes exposed to oxLDLs acquire a prothrombotic phenotype by expressing functional TF on their membrane, as already reported for monocytes, ${ }^{32}$ independently on the potential role of oxLDLs as a non-self-antigen, namely via activation of LOX-1, and that within atherosclerotic lesions, these cells might directly contribute to the onsite thrombotic process in vivo, linking atherosclerosis, immunity and thrombosis in a single multi-step process.

It is widely recognized that atherosclerosis is an inflammatory disease, where immunocompetent cells producing pro-inflammatory cytokines are abundant in atherosclerotic lesions. ${ }^{33}$ In addition, important components of the atherosclerotic plaque include dead cells, debris, and modified forms of lipids, particularly oxLDLs. ${ }^{34}$ It has been convincingly demonstrated that $\mathrm{T}$ cells with pro-inflammatory properties (i.e. Th1 subsets) play a key role not only in initiating the development of the atherosclerotic plaque, but also in promoting its complication (rupture, fissuration, etc.), leading to the clinical occurrence of ACS. For example, several studies have demonstrated that complicated plaques show a higher content of inflammatory cells, often located near the site of rupture, thus suggesting an active role in plaque rupture (for review, see ref. 34). In a study from our group employing coronary plaque specimens obtained during directional coronary atherectomy from living patients with ACS we have investigated the T-cell repertoire, demonstrating a specific, immune-driven activation of $T$ cells within unstable plaques. ${ }^{3}$ In particular, we have shown that unstable plaques contain a much greater T-cell infiltration than stable plaques and that the T-cell receptor (TCR) repertoire within the unstable plaques was highly skewed in all patients with ACS, as compared to patients with stable angina, indicating a specific antigen-driven $\mathrm{T}$-cell recruitment within the culprit lesions of patients 
A

A
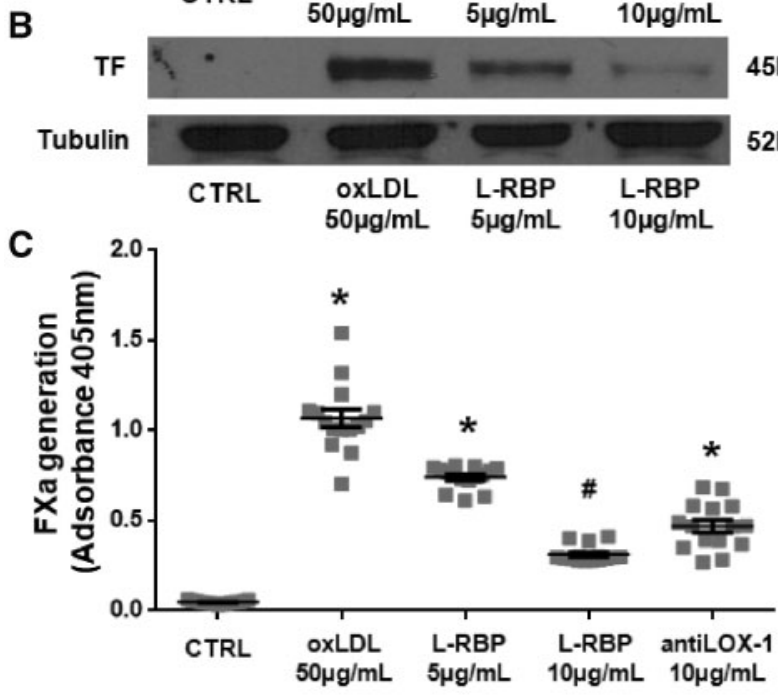
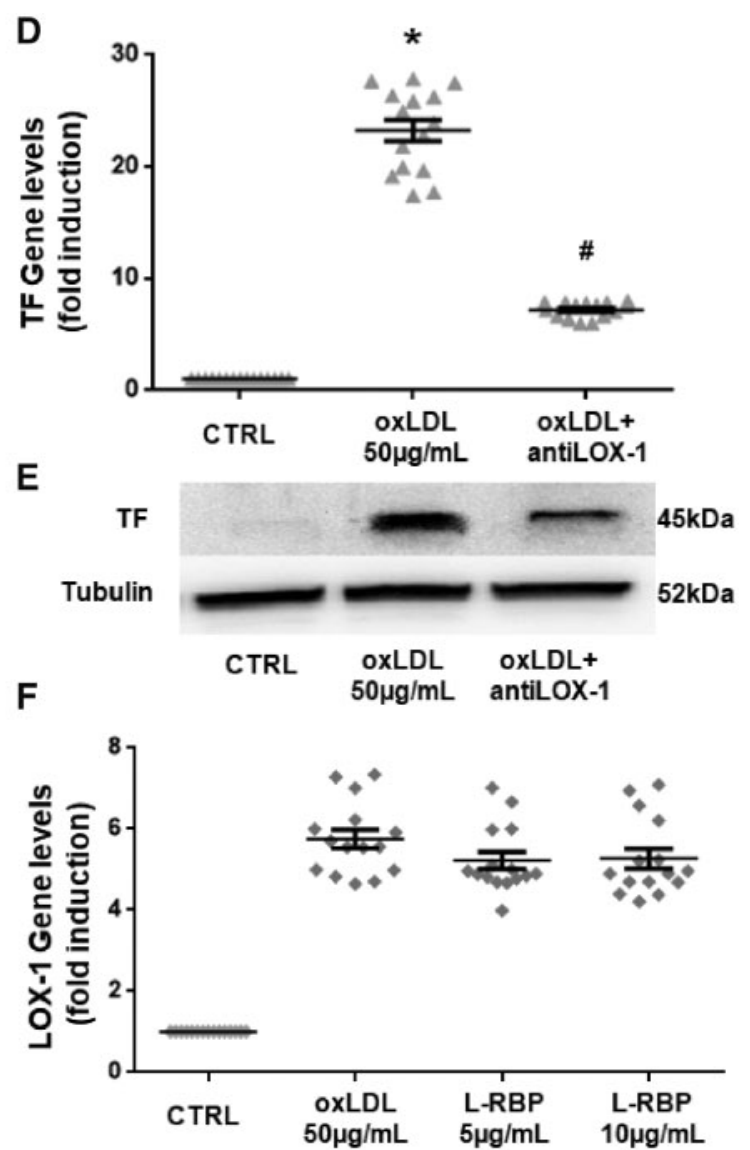

Figure 5 Effects of LOX-1 inhibition on TF and LOX-1 expression by T-lymphocytes stimulated with oxLDLs. T cells were pre-incubated with a lowdensity lipoprotein receptor blocking peptide (L-RBP) or anti-LOX-1 blocking antibody and then stimulated with oxLDLs. (A and B) L-RBP resulted in a dose-dependent suppression of TF expression at gene and protein levels ( $* P<0.001,{ }^{\#} P<0.01$ vs. Control; one-way ANOVA with Tukey's post hoc test). (C) TF procoagulant activity is significantly affected by L-RBP and anti-LOX-1 blocking antibody pre-treatment $\left({ }^{*} P<0.001,{ }^{\#} P<0.01\right.$ vs. Control; one-way ANOVA with Tukey's post hoc test). ( $D$ and $E$ ) Anti-LOX-1 blocking antibody resulted in a significant suppression of TF expression at gene and protein levels $\left(* P<0.001,{ }^{*} P<0.01\right.$ vs. Control; one-way ANOVA with Tukey's post hoc test). $(F)$ In contrast, L-RBP had no effect on LOX-1 gene expression (D). Each column represents the mean \pm SE of 15 experiments in triplicate.

with ACS. ${ }^{3}$ However, the search for of the putative antigen(s) responsible for the local activation of the $T$ cells still remains elusive.

According to the leading hypothesis, modified forms of LDLs, including oxLDLs may play an important role in the occurrence of plaque complication by being recognized as non-self-antigens by $\mathrm{T}$-lymphocytes. Previous studies have indeed suggested that oxLDLs can function as Tcell antigens in the context of atherogenesis; ${ }^{35,36}$ interestingly, Liu et al. ${ }^{7}$ have recently demonstrated that enzymatically modified forms of LDLs, but not native LDLs, promote dendritic cell maturation and T-cell activation, suggesting an involvement of the TCR. Whether oxLDLs may induce TF in dendritic cells via activation of LOX-1 is not known at the moment; it should be pointed out, however, that in the present study we provide evidence of the interplay between T-lymphocytes and oxLDLs in a way different from the "classical' TCR-mediated activation of lymphocytes. In fact, we have shown that oxLDLs may activate $T$ cells via induction of the scavenger receptor, LOX-1. Binding of LOX-1 to oxLDLs then induced expression of functional TF on the T-cell membrane. Confocal microscopy experiments confirmed that LOX-1 is almost undetectable in unstimulated $T$ cells, while it is highly expressed on T-cell membrane following exposure to oxLDLs.

Another potential mechanism by which oxLDLs may activate T-lymphocytes is represented by an increase in oxidative stress. For example, it is well established that oxLDLs increase intracellular levels of ROS and lipid peroxidation end-products. ${ }^{28}$ To verify if TF expression was related to an oxLDL-induced oxidative stress, we have conducted two different sets of experiments: first, we have quantified lipid peroxidation in T cells stimulated with oxLDLs or hydrogen peroxide. Secondly, we have measured TF and LOX-1 expression in $\mathrm{H}_{2} \mathrm{O}_{2}$-treated cells and have compared it with that obtained after oxLDL stimulation. Although $\mathrm{H}_{2} \mathrm{O}_{2}$ induced significantly higher levels of lipid peroxidation than oxLDLs, the effects on TF expression were of a significantly lesser order of magnitude. Interestingly, $\mathrm{H}_{2} \mathrm{O}_{2}$ induced high levels of LOX-1 gene as early as $4 \mathrm{~h}$ in a time- and dose-dependent manner. We may speculate that peroxidation by $\mathrm{H}_{2} \mathrm{O}_{2}$ induces early expression of LOX-1, that is used by oxLDLs for binding and amplification of LOX-1 expression in line with other observation in different cells type. ${ }^{37,38}$ More important, 
A

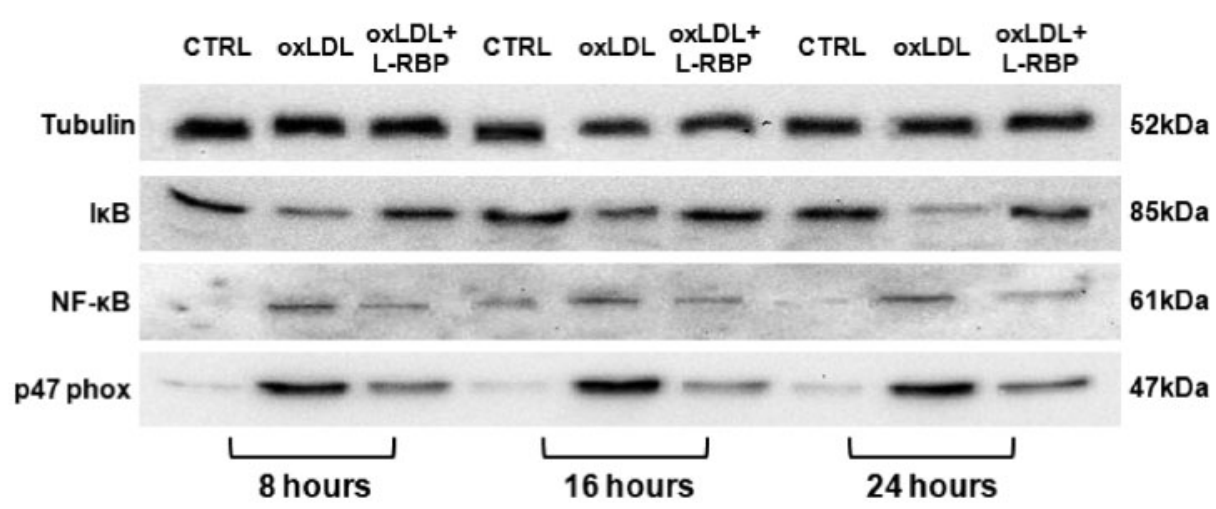

B

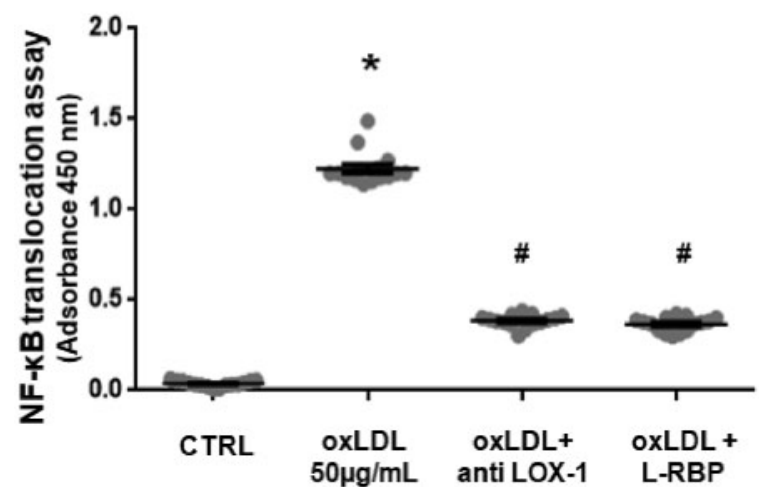

C

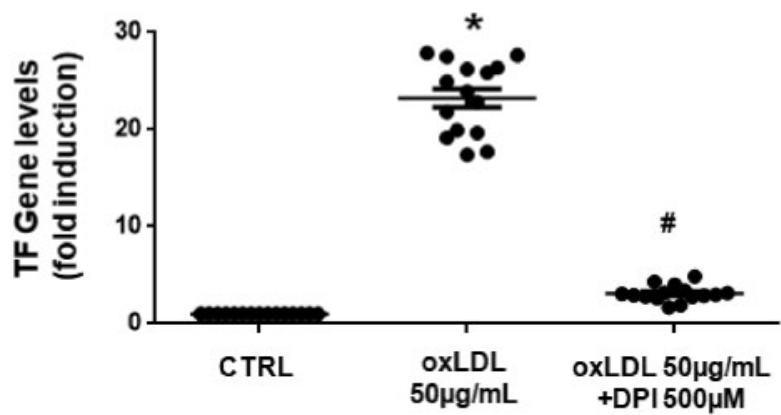

Figure 6 Intracellular molecular pathways activated by oxLDL stimulation of T-lymphocytes. T-lymphocytes were stimulated with oxLDLs for 8, 16, and 24h. Cell lysates were used to measure cytosolic NADPH and NF-kB activation. (A) Western blots analyses. oxLDLs/LOX-1 interaction induced NAPDH oxidase activation, as shown by the increased levels of $\mathrm{p} 47$ phox (one of the intracellular subunit of the NADPH system) that in turn resulted in increased cytosolic levels of NF-KB and reduced levels of IKB. Conversely, pre-incubation with L-RBP, reduced significantly p47-phox and NF- $\mathrm{KB}$ and increased IKB. (B) NF-KB translocation to the nucleus is significantly reduced by L-RBP and anti-LOX-1 blocking antibody pre-incubation ( ${ }^{* P}<0.01$ vs. CTRL, ${ }^{\#} P<0.01$ vs. oxLDL; one-way ANOVA with Tukey's post hoc test). (C) T cells pre-incubated with DPI (500 $\mu \mathrm{M})$ resulted in a significant inhibition of TF gene expression $\left({ }^{* P}<0.01\right.$ vs. CTRL, ${ }^{\#}<0.01$ vs. oxLDL; one-way ANOVA with Tukey's post hoc test).

in oxLDL-treated cells, pre-incubation with SOD and catalase did not affect significantly TF expression. In addition, pre-treatment with Tempol, an intracellular antioxidant, did not significantly affect oxLDL-induced TF expression. These findings, together with the observation that in $T$ cells stimulated with oxLDLs in presence of L-RBP, an inhibitor of LDL binding to its receptor, or a blocking anti-LOX-1 antibody, TF expression was almost completely abolished clearly indicate that the effects of oxLDLs on T cells are largely mediated via interaction with LOX-1. Finally, one additional observation further supports this conclusion: binding of oxLDLs to LOX-1 activates NADPH oxidase on the cell membrane that results in rapid formation of intracellular ROS, ${ }^{29}$ which in turn activate the redox-sensitive NF- $\mathrm{KB}$ signalling pathway, generating different intracellular responses. ${ }^{30,31}$

The NADPH oxidase (NOX) is a multicomponent enzyme made up of six subunits: a Rho guanosine triphosphatase (GTPase) and five 'phox' units, one of which is $\mathrm{p} 47 .{ }^{39} \mathrm{NOX}$ is known to be one of the major sources of intracellular ROS. Once activated, the G proteins Rac1 or Rac2 and the phosphorylated cytoplasmic $p 47$ phox subunit initiate migration of the cytosolic elements to the plasma membrane, to form a functional complex that generates ROS. ${ }^{40}$ The $\mathrm{p} 47$ phox acts as a regulatory subunit of NOX to initiate assembly of active oxidase, which is important for NOX activation. ${ }^{39}$ It has been reported that inhibition of $\mathrm{p} 47$ phox abrogated NOX function and diminished ROS production in ovarian and prostate cancer cells. ${ }^{41}$ Depending on the level of ROS, different redox-sensitive transcription factors are activated and co-ordinate distinct biological responses. An intermediate amount of ROS triggers an inflammatory response through the activation of NF-KB and AP-1. $N F-\kappa B$ was the first transcription factor shown to be redox-regulated. ${ }^{42}$

In the present study, oxLDLs/LOX-1 interaction induced NAPDH oxidase activation as shown by the increased levels of $p 47$ that in turn resulted in increased cytosolic levels of NF- $\kappa B$ and reduced levels of $I_{\kappa} B$. Conversely, pre-incubation with L-RBP significantly blunted the increase in $\mathrm{p} 47$ and NF- $\kappa B$, while it increased $1 \kappa B$. In line with these results is the observation that the use of DPI, a potent NAPDH oxidase inhibitor, significantly reduced oxLDL-induced TF expression.

In conclusion, the present study shows for the first time that $T$ cells may acquire a pro-thrombotic phenotype via expression of functional TF in response to oxLDLs and that this phenomenon is largely mediated 

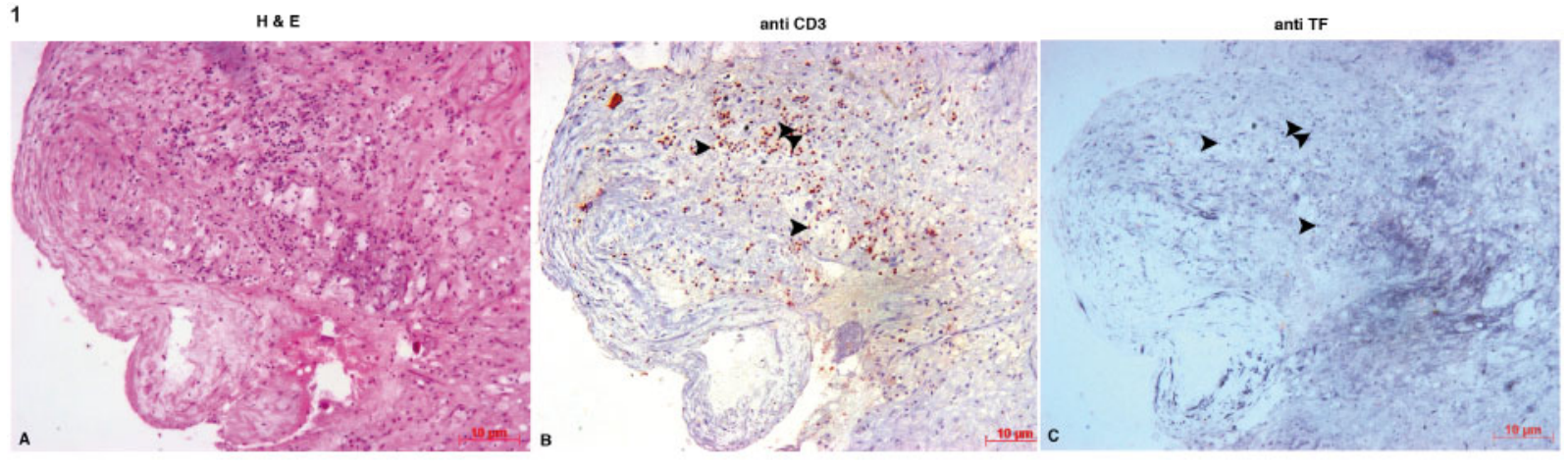

2
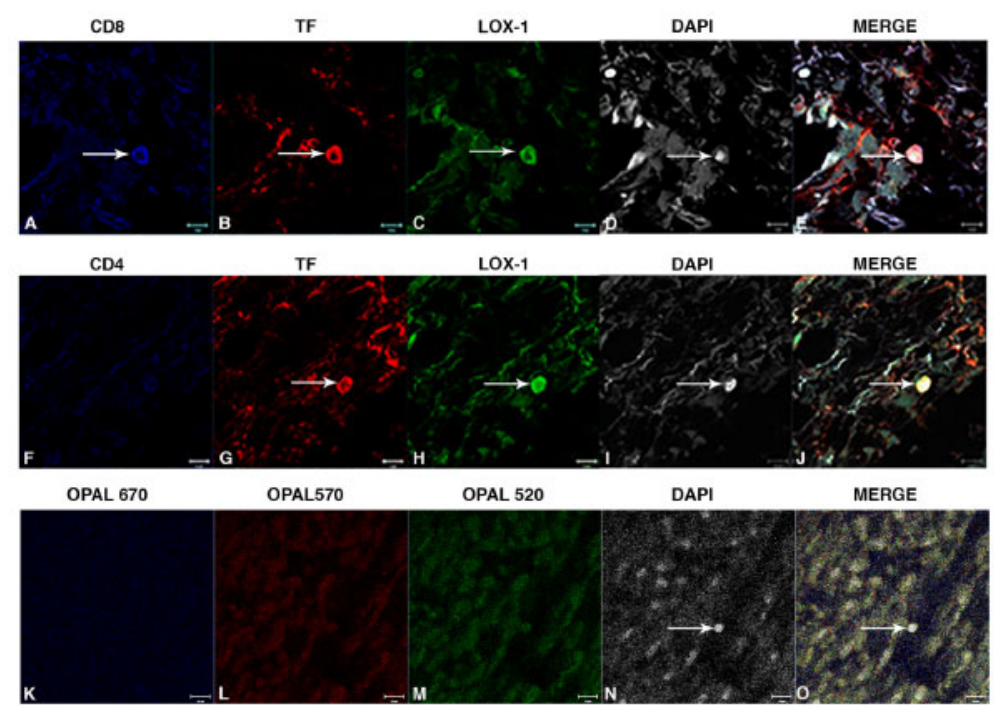

Figure 7 Panel 1: Immunohistochemistry and immunofluorescence of human carotid atherosclerotic plaques. Atherosclerotic plaques collected from patients undergoing TEA resulted cellularly enriched as evidenced by haematoxylin and eosin staining $(A)$. Interestingly, some of these cells were positive for CD3 antigen ( $B$, arrows), and also expressing TF ( $C$, arrows). Panel 2: T-lymphocytes characterization in atherosclerotic lesion. In atheroma, cytotoxic T-lymphocytes $\left(C D 8^{+}\right)$, express TF and LOX-1. Tissue sections from representative carotid atheroma were stained, as described in Section 2, with antibodies anti-CD8 $(A)$, anti-CD4 $(F)$, anti-TF ( $B$ and $G)$, and LOX-1 $(C$ and $H)$. Section from atheroma shows cell stained with anti-CD8 antibody (Blu, $A$ white arrow), the same cell is also stained by anti-TF antibody (Red, $B$ white arrow), and anti-LOX-1 antibody (Green, $C$ white arrow). In sequential section from the same atheroma, antibody anti-CD4 gave no staining (Blu, $F$ ) while there are cells stained by anti-TF antibody (Red, $G$ white arrow) and anti-LOX-1 antibody (Green, $H$ white arrow). As negative control a section was stained only with Opal Polymer horseradish peroxidase (HRP) anti-Mouse-Rabbit secondary antibody solution and then incubated with the Opal Fluorophore $670(K), 570(L)$, and $520(M)$. Nuclei were counterstained with DAPI (white D, I, N, white arrow), Merge (white arrow) is shown in E,J, $O$ (bar $=10 \mu \mathrm{m})$.

by activation of LOX-1. Taken together with previous studies $3,9,43,44$ data of the present study support the relevant contribution of $T$ cells in atherosclerosis and thrombosis. Considering the key role of LOX-1 in this mechanism, future studies exploring the effects of its modulation in the clinical scenario of acute cardiovascular events are warranted.

\section{Supplementary material}

Supplementary material is available at Cardiovascular Research online.

\section{Acknowledgements}

We thank Laura Marra, PhD from SC Cell Biology and Biotherapy, Istituto Nazionale Tumori IRCCS, Fondazione G. Pascale, Naples, Italy, for her support in flow cytometry analysis.

Conflict of interest: none declared.

\section{Funding}

This study was supported by the Progetti di Ricerca di Interesse Nazionale (PRIN2009FJX9KW_001).

\section{References}

1. Weber $\mathrm{C}$, Noels $\mathrm{H}$. Atherosclerosis: current pathogenesis and therapeutic options. Nat Med 2011;17:1410-1422

2. Getz GS, Reardon CA. The mutual interplay of lipid metabolism and the cells of the immune system in relation to atherosclerosis. Clin Lipidol 2014;9:657-671.

3. De Palma R, Del Galdo F, Abbate G, Chiariello M, Calabro R, Forte L, Cimmino G, Papa MF, Russo MG, Ambrosio G, Giombolini C, Tritto I, Notaristefano S, Berrino L, Rossi F, Golino P. Patients with acute coronary syndrome show oligoclonal T-cell recruitment within unstable plaque: evidence for a local, intracoronary immunologic mechanism. Circulation 2006;113:640-646.

4. Steinberg D, Witztum JL. Oxidized low-density lipoprotein and atherosclerosis. Arterioscler Thromb Vasc Biol 2010;30:2311-2316.

5. Ketelhuth DF, Hansson GK. Cellular immunity, low-density lipoprotein and atherosclerosis: break of tolerance in the artery wall. Thromb Haemost 2011;106: 779-786. 
6. Nilsson J, Nordin Fredrikson G, Schiopu A, Shah PK, Jansson B, Carlsson R. Oxidized $\mathrm{LDL}$ antibodies in treatment and risk assessment of atherosclerosis and associated cardiovascular disease. Curr Pharm Des 2007;13:1021-1030.

7. Liu A, Ming JY, Fiskesund R, Ninio E, Karabina SA, Bergmark C, Frostegard AG, Frostegard J. Induction of dendritic cell-mediated T-cell activation by modified but not native low-density lipoprotein in humans and inhibition by annexin a5: involvement of heat shock proteins. Arterioscler Thromb Vasc Biol 2015;35:197-205.

8. Libby P, Hansson GK. Inflammation and immunity in diseases of the arterial tree: players and layers. Circ Res 2015;116:307-311.

9. De Palma R, Cirillo P, Ciccarelli G, Barra G, Conte S, Pellegrino G, Pasquale G, Nassa G, Pacifico F, Leonardi A, Insabato L, Cali G, Golino P, Cimmino G. Expression of functional tissue factor in activated T-lymphocytes in vitro and in vivo: a possible contribution of immunity to thrombosis? Int J Cardiol 2016;218:188-195.

10. Sawamura T, Kume N, Aoyama T, Moriwaki H, Hoshikawa H, Aiba Y, Tanaka T, Miwa S, Katsura Y, Kita T, Masaki T. An endothelial receptor for oxidized lowdensity lipoprotein. Nature 1997;386:73-77.

11. Mehta JL, Chen J, Hermonat PL, Romeo F, Novelli G. Lectin-like, oxidized lowdensity lipoprotein receptor-1 (LOX-1): a critical player in the development of atherosclerosis and related disorders. Cardiovasc Res 2006;69:36-45.

12. Graham LS, Parhami F, Tintut Y, Kitchen CM, Demer LL, Effros RB. Oxidized lipids enhance RANKL production by $T$ lymphocytes: implications for lipid-induced bone loss. Clin Immunol 2009;133:265-275.

13. Cimmino G, Ibanez B, Vilahur G, Speidl WS, Fuster V, Badimon L, Badimon JJ. Upregulation of reverse cholesterol transport key players and rescue from global inflammation by ApoA-I(Milano). J Cell Mol Med 2009;13:3226-3235.

14. Sakamoto N, Ishibashi T, Sugimoto K, Sawamura T, Sakamoto T, Inoue N, Saitoh S, Kamioka M, Uekita H, Ohkawara H, Suzuki K, Teramoto T, Maruyama Y, Takeishi Y. Role of LOX-1 in monocyte adhesion-triggered redox, Akt/eNOS and $\mathrm{Ca}^{2+}$ signaling pathways in endothelial cells. J Cell Physiol 2009;220:706-715.

15. Li D, Liu L, Chen H, Sawamura T, Ranganathan S, Mehta JL. LOX-1 mediates oxidized low-density lipoprotein-induced expression of matrix metalloproteinases in human coronary artery endothelial cells. Circulation 2003;107:612-617.

16. Cirillo P, Conte S, Cimmino G, Pellegrino G, Ziviello F, Barra G, Sasso FC, Borgia F, De Palma R, Trimarco B. Nobiletin inhibits oxidized-LDL mediated expression of tissue factor in human endothelial cells through inhibition of NF-kappaB. Biochem Pharmacol 2017;128:26-33.

17. Dong W, Li Z, Chen Y, Zhang L, Ye Z, Liang H, Li R, Xu L, Zhang B, Liu S, Wang W, Li C, Luo J, Shi W, Liang X. NADPH oxidase inhibitor, diphenyleneiodonium prevents necroptosis in HK-2 cells. Biomed Rep 2017;7:226-230.

18. Malmberg KJ, Arulampalam V, Ichihara F, Petersson M, Seki K, Andersson T, Lenkei R, Masucci G, Pettersson S, Kiessling R. Inhibition of activated/memory $(\mathrm{CD} 45 \mathrm{RO}(+)) \mathrm{T}$ cells by oxidative stress associated with block of NF-kappaB activation. J Immunol 2001;167:2595-2601.

19. Toniolo A, Buccellati C, Pinna C, Gaion RM, Sala A, Bolego C. Cyclooxygenase-1 and prostacyclin production by endothelial cells in the presence of mild oxidative stress. PLoS One 2013;8:e56683.

20. Venkatesha VA, Venkataraman S, Sarsour EH, Kalen AL, Buettner GR, Robertson LW, Lehmler HJ, Goswami PC. Catalase ameliorates polychlorinated biphenylinduced cytotoxicity in nonmalignant human breast epithelial cells. Free Radic Biol Med 2008;45:1094-1102.

21. Preston TJ, Muller WJ, Singh G. Scavenging of extracellular $\mathrm{H}_{2} \mathrm{O}_{2}$ by catalase inhibits the proliferation of HER-2/Neu-transformed rat-1 fibroblasts through the induction of a stress response. J Biol Chem 2001;276:9558-9564.

22. Khabour OF, Alzoubi KH, Mfady DS, Alasseiri M, Hasheesh TF. Tempol protects human lymphocytes from genotoxicity induced by cisplatin. Int J Clin Exp Med 2014;7: 982-988.

23. Alzoubi KH, Khabour OF, Jaber AG, Al-Azzam SI, Mhaidat NM, Masadeh MM. Tempol prevents genotoxicity induced by vorinostat: role of oxidative DNA damage. Cytotechnology 2014;66:449-455.

24. Cali G, Zannini M, Rubini P, Tacchetti C, D'Andrea B, Affuso A, Wintermantel T, Boussadia O, Terracciano D, Silberschmidt D, Amendola E, De Felice M, Schutz G, Kemler R, Di Lauro R, Nitsch L. Conditional inactivation of the E-cadherin gene in thyroid follicular cells affects gland development but does not impair junction formation. Endocrinology 2007;148:2737-2746.

25. Cali G, Gentile F, Mogavero S, Pallante P, Nitsch R, Ciancia G, Ferraro A, Fusco A, Nitsch L. CDH16/Ksp-cadherin is expressed in the developing thyroid gland and is strongly down-regulated in thyroid carcinomas. Endocrinology 2012;153:522-534.

26. Stack EC, Wang C, Roman KA, Hoyt CC. Multiplexed immunohistochemistry, imaging, and quantitation: a review, with an assessment of Tyramide signal amplification, multispectral imaging and multiplex analysis. Methods 2014;70:46-58.

27. Maziere C, Marcheux V, Louandre C, Maziere JC. Oxidized low density lipoprotein induces the cyclin-dependent kinase inhibitor p21(waf1) and the tumor suppressor Rb. Biochem Biophys Res Commun 2002;293:1327-1332.

28. Maziere C, Meignotte A, Dantin F, Conte MA, Maziere JC. Oxidized LDL induces an oxidative stress and activates the tumor suppressor p53 in MRC5 human fibroblasts. Biochem Biophys Res Commun 2000;276:718-723.

29. Wang X, Son YO, Chang Q, Sun L, Hitron JA, Budhraja A, Zhang Z, Ke Z, Chen F, Luo J, Shi $X$. NADPH oxidase activation is required in reactive oxygen species generation and cell transformation induced by hexavalent chromium. Toxicol Sci 2011;123: 399-410.

30. Jiang Q, Wang D, Han Y, Han Z, Zhong W, Wang C. Modulation of oxidized-LDL receptor-1 (LOX1) contributes to the antiatherosclerosis effect of oleanolic acid. Int J Biochem Cell Biol 2015;69:142-152.

31. Xu S, Ogura S, Chen J, Little PJ, Moss J, Liu P. LOX-1 in atherosclerosis: biological functions and pharmacological modifiers. Cell Mol Life Sci 2013;70:2859-2872.

32. Owens AP 3rd, Passam FH, Antoniak S, Marshall SM, McDaniel AL, Rudel L, Williams JC, Hubbard BK, Dutton JA, Wang J, Tobias PS, Curtiss LK, Daugherty A, Kirchhofer D, Luyendyk JP, Moriarty PM, Nagarajan S, Furie BC, Furie B, Johns DG, Temel RE, Mackman N. Monocyte tissue factor-dependent activation of coagulation in hypercholesterolemic mice and monkeys is inhibited by simvastatin. J Clin Invest 2012;122: 558-568.

33. Frostegard J, Ulfgren AK, Nyberg P, Hedin U, Swedenborg J, Andersson U, Hansson GK. Cytokine expression in advanced human atherosclerotic plaques: dominance of pro-inflammatory (Th1) and macrophage-stimulating cytokines. Atherosclerosis 1999; 145:33-43

34. Libby P, Ridker PM, Hansson GK. Progress and challenges in translating the biology of atherosclerosis. Nature 2011;473:317-325.

35. Stemme S, Faber B, Holm J, Wiklund O, Witztum JL, Hansson GK. T lymphocytes from human atherosclerotic plaques recognize oxidized low density lipoprotein. Proc Natl Acad Sci USA 1995;92:3893-3897.

36. Frostegard J, Wu R, Giscombe R, Holm G, Lefvert AK, Nilsson J. Induction of T-cell activation by oxidized low density lipoprotein. Arterioscler Thromb 1992;12:461-467.

37. Nagase M, Ando K, Nagase T, Kaname S, Sawamura T, Fujita T. Redox-sensitive regulation of lox-1 gene expression in vascular endothelium. Biochem Biophys Res Commun 2001;281:720-725.

38. Wang R, Ding G, Liang W, Chen C, Yang H. Role of LOX-1 and ROS in oxidized low-density lipoprotein induced epithelial-mesenchymal transition of NRK52E. Lipids Health Dis 2010;9:120.

39. Panday A, Sahoo MK, Osorio D, Batra S. NADPH oxidases: an overview from structure to innate immunity-associated pathologies. Cell Mol Immunol 2015;12:5-23.

40. Lambeth JD. NOX enzymes and the biology of reactive oxygen. Nat Rev Immunol 2004;4:181-189.

41. Xia C, Meng Q, Liu LZ, Rojanasakul Y, Wang XR, Jiang BH. Reactive oxygen species regulate angiogenesis and tumor growth through vascular endothelial growth factor. Cancer Res 2007;67:10823-10830.

42. Schreck R, Rieber P, Baeuerle PA. Reactive oxygen intermediates as apparently widely used messengers in the activation of the NF-kappa $B$ transcription factor and HIV-1. EMBO J 1991;10:2247-2258.

43. Cirillo P, Cimmino G, D'Aiuto E, Di Palma V, Abbate G, Piscione F, Golino P, De Palma R. Local cytokine production in patients with acute coronary syndromes: a look into the eye of the perfect (cytokine) storm. Int J Cardiol 2014;176:227-229.

44. Cirillo P, Golino P, Piscione F, Cimmino G, Petrillo G, Abbate G, De Palma R. Transcoronary Th-17 lymphocytes and acute coronary syndromes: new evidence from the crime scene? Int J Cardiol 2011;153:215-216.

\section{Translational perspectives}

Despite significant advancements have been made in antithrombotic therapy, current strategies still fail to prevent acute thrombotic coronary events in a substantial number of patients, indicating that the complex mechanisms underlying the pathophysiology of ACS are not fully elucidated. The present study demonstrates, for the first time, that T-lymphocytes may express functional TF in response to oxLDLs via mechanisms other than the "classical' activation of the T-cell receptor, namely via interaction with LOX-1. Further studies aimed at interfering with LOX-1 in T-lymphocytes might offer innovative and additional therapeutical approaches for ACS patients. 